SILVA, PHS; PALARETTI, LF; CECÍLIO FILHO, AB; SILVA, YF. 2020. Nitrogen levels via fertigation and irrigation depths in the arugula culture. Horticultura Brasileira 38: 343-349. DOI: http://dx.doi.org/10.1590/s0102-053620200401

\title{
Nitrogen levels via fertigation and irrigation depths in the arugula culture
}

\author{
Paulo Henrique S Silva ${ }^{1} \mathbb{D}$; Luiz Fabiano Palaretti ${ }^{1} \mathbb{D}$; Arthur Bernardes Cecílio Filho' ${ }^{1} \mathbb{D}$; Yane F da Silva ${ }^{2} \mathbb{D}$
}

${ }^{1}$ Universidade Estadual Paulista (UNESP-FCAV), Jaboticabal-SP, Brasil; ${ }^{2}$ Universidade de Campinas (UNICAMP), Campinas-SP; Brasil; phsoares18@yahoo.com.br; luiz.f.palaretti@unesp.br (author for correspondence); arthur.cecilio@unesp.br; yanefsilva@gmail.com

\begin{abstract}
In vegetables, especially the leafy ones, nitrogen $(\mathrm{N})$ and water are essential in its growth, being $\mathrm{N}$ the second most absorbed and identified nutrient in the arugula leaf tissue. Water is essential for horticultural crops, so its use must be rational in order to achieve high yield. The objective of this study was to evaluate the effect of nitrogen levels and irrigation depths on the productive characteristics, the total leaf chlorophyll index (ICF) and nitrogen contents in the arugula culture. The experiment was arranged in a randomized block design subdivided in plots, with two factors: A) nitrogen levels applied in coverage $\left(25,50,100,125\right.$ and $\left.150 \mathrm{mg} \mathrm{dm}^{-3}\right)$ and $\left.\mathrm{B}\right)$ irrigation depths [(50 and $100 \%$ of the available water capacity (AWC)]. At harvest, 37 days after transplantation (DAT), we observed a significant effect of the treatments when individually analyzed, and also a significant interaction between factors of the analyzed variables. The nitrogen content in the plant showed no effect for irrigation depths. However, the highest content was found in the level of $129 \mathrm{mg} \mathrm{dm}^{-3}(27.8 \mathrm{~g}$ $\mathrm{kg}^{-1}$ ), corresponding to an increase of $26 \%$ in relation to the lowest level $\left(25 \mathrm{mg} \mathrm{dm}-3 ; 22.07 \mathrm{~g} \mathrm{~kg}^{-1}\right)$. In conclusion, the supply of 150 $\mathrm{mg} \mathrm{dm}^{-3}$ nitrogen and full irrigation management (100\% of AWC) provided substantial increase in height, leaf area and fresh mass of aerial part of the plant.
\end{abstract}

Keywords: Eruca sativa, leaf chlorophyll index, leafy vegetables, water complementation, plant growth.

\section{RESUMO \\ Doses de nitrogênio via fertirrigação e lâminas de irrigação na cultura da rúcula}

Nas hortaliças, especialmente folhosas, são fundamentais para o crescimento das plantas o nitrogênio $(\mathrm{N})$ e a água, sendo o $\mathrm{N} \mathrm{o}$ segundo nutriente mais absorvido e identificado no tecido foliar da rúcula. A água é essencial para cultivos hortícolas; por isso o seu uso deve ser racional para que altas produtividades sejam alcançadas. Objetivou-se avaliar o efeito de níveis de nitrogênio via fertirrigação e lâminas de irrigação nas características produtivas, no índice total de clorofila foliar (ICF) e teor de nitrogênio na cultura da rúcula. $\mathrm{O}$ experimento foi arranjado no delineamento de blocos casualizados em parcelas subdivididas, sendo dois fatores: A) níveis de nitrogênio aplicados em cobertura $\left(25,50,100,125\right.$ e $\left.150 \mathrm{mg} \mathrm{dm}^{-3}\right)$ e B) lâminas de irrigação 50 e $100 \%$ da capacidade de água disponível (CAD). $\mathrm{Na}$ colheita, aos 37 dias após o transplantio (DAT) houve efeito significativo dos tratamentos isoladamente, e também interação dos tratamentos das variáveis analisadas. As lâminas de irrigação não foram significantes para o teor de nitrogênio na planta. Entretanto, o maior teor foi verificado no nível de $129 \mathrm{mg} \mathrm{dm}^{-3}\left(27,8 \mathrm{~g} \mathrm{~kg}^{-1}\right)$, correspondendo a um incremento de $26 \%$ em relação ao nível de $25 \mathrm{mg} \mathrm{dm}{ }^{-3}\left(22,07 \mathrm{~g} \mathrm{~kg}^{-1}\right)$. Portanto, o fornecimento de $150 \mathrm{mg}$ $\mathrm{dm}^{-3}$ de nitrogênio e o manejo da irrigação plena (100\% da CAD) proporcionaram incremento substancial na altura, área foliar e massa fresca da parte aérea.

Palavras-chave: Eruca sativa, índice de clorofila foliar, vegetais folhosos, complementação hídrica, rendimento agronômico.

Received on June 11, 2020; accepted on October 1, 2020

L ettuce is the most produced and consumed leafy vegetable in Brazil. However arugula (Eruca sativa) in the last decade has been acquiring an important place in the market, for standing out in modern diets due to the bitter taste, resulting from various glucosinolates and other sulfurcontaining compounds in edible parts (Piślewska-Bednarek et al., 2018).

According to Maia et al. (2007), the arugula has nutritional and phytotherapeutic properties, is rich in vitamins and fibers, in addition to the presence of minerals such as calcium, sulfur, iron, phosphorus and potassium compounds.

In vegetables, especially the leafy ones, nitrogen $(\mathrm{N})$ plays a fundamental role in the growth and yield of harvested products. On this matter, an adequate nitrogen supply is associated with high photosynthetic activity and vigorous vegetative growth (Castellane, 1994; Filgueira, 2000). N is the second most absorbed nutrient identified in arugula leaf tissue (Grangeiro et al., 2011), due to its influence on vegetal development (Purquerio et al., 2007).

To increase crop productivity, $\mathrm{N}$ fertilization management is essential, once low levels can lead to plants nutritional deficiency (Coelho et al., 2018). Nutrients and water are the main factors on crop yield. Water is essential to increase crop production; so it must be applied in the best way to achieve high and satisfactory yields. Aiming to reach that goal, knowledge about crop growth, as well as the quantities to be applied and the periods of greatest demand, are factors that require information of soilwater-plant-atmosphere relationships and their yield under different conditions (Aragão et al., 2012). 
Water supplementation in horticultural crops is a necessity, even in the rainy season, depending on drought occurrence, as these crops are very susceptible to water stress (Aleman et al., 2014), mainly due to large variations in soil water levels (Kassam \& Doorenbos, 1994). Irrigation is one of the technological treatments available that most provides increase in crops productivity and improves vegetables quality (Bilibio et al., 2010).

While in the current literature reports lack information on the effects of different levels of $\mathrm{N}$ to be applied via fertigation on the growth of arugula, fertilizer recommendations for the crop are similar to several other leafy vegetables, most likely due to few studies, mainly related to the nutrients demand (Purquerio et al., 2007; Grangeiro et al., 2011). Therefore, applying fertigation, it is possible to mix fertilizers and water levels to obtain a uniform distribution in the total area, avoiding excessive concentration of the fertilizers and saving water, corroborating for the reduction of the environmental impact and contributing to the absorption of the nutrient where the roots are more active.

The objective of this work was to investigate the effect of nitrogen levels and irrigation depths on the agronomic performance, chlorophyll and nitrogen content in the arugula culture.

\section{MATERIAL AND METHODS}

\section{Site description and experimental treatments}

The experiment was carried out from May 16 to June 22, 2018, in the São Paulo State University "Júlio de Mesquita Filho", School of Agricultural and Veterinary Studies, Jaboticabal-SP ( $21^{\circ} 15^{\prime} 22^{\prime \prime} \mathrm{S}, 48^{\circ} 18^{\prime} 58^{\prime \prime} \mathrm{W}, 595$ meter altitude).

The climate of the region is classified as rainy tropical with dry winters and the coldest month with an average temperature above $18^{\circ} \mathrm{C}$, of the $A w$ type according to the Köppen-Geiger classification (Andre \& Garcia, 2015).

During the experimental period, the climatological data of maximum, average and minimum air temperatures were $35.7^{\circ} \mathrm{C}, 28.3^{\circ} \mathrm{C}$ and $22.2^{\circ} \mathrm{C}$; relative humidity of $65.8 \%, 42 \%$ and $14.2 \%$, respectively, and solar radiation average and maximum of $14.5 \mathrm{MJ} \mathrm{m}^{-2}$ and 549.7 $\mathrm{MJ} \mathrm{m}^{-2}$. These data were obtained from an agrometeorological micro station installed inside the greenhouse of UNESP-FCAV, Jaboticabal-SP.

\section{Experimental evolution}

The agricultural greenhouse is a nonclimate-controlled chapel, covered with 150 micron low density polyethylene, with anti-insect screen on the sides. The greenhouse had dimensions of 30 $\mathrm{m}$ long, $6.9 \mathrm{~m}$ wide and $3.5 \mathrm{~m}$ in height. Each experimental plot consisted of a pot with capacity for $6 \mathrm{dm}^{-3}$ soil, containing two plants.

The substrate used in the pots was a mixture of chicken manure, an Eutrophic Red Latosol, with clayey texture (Santos et al., 2018) and castor cake in a proportion of 3:1, later sieved, whose chemical characterization was made according to the Claessen (1997). The substrate chemical characteristics prior to the installation of the experiments, were: $\mathrm{pH}_{(\mathrm{CaCl})}=6.3$; organic matter $=$ $24 \mathrm{mg} \mathrm{dm}^{-3} ; \mathrm{P}_{(\text {Resin })}=52 \mathrm{mg} \mathrm{dm}^{-3} ; \mathrm{S}=11$ $\mathrm{mg} \mathrm{dm}{ }^{-3} ; \mathrm{Ca}=30 \mathrm{mmol}_{\mathrm{c}} \mathrm{dm}^{-3} ; \mathrm{Mg}=9$ $\mathrm{mmol}_{\mathrm{c}} \mathrm{dm}^{-3} ; \mathrm{K}=2.3 \mathrm{mmol}_{\mathrm{c}} \mathrm{dm}^{-3} ; \mathrm{H}+\mathrm{Al}$ $=17 \mathrm{mmol}_{\mathrm{c}} \mathrm{dm}^{-3}$; and base saturation $(\mathrm{V})=71 \%$.

According to soil chemical analysis, liming was not necessary to reach base saturation required by arugula. The $4-\mathrm{cm}$ heigh plantlets were planted on May 16, using arugula cv. 'Folha larga'. On the ninth day after transplantation (DAT) plants were thinned, leaving two plants per pot.

Planting fertilization was performed based on soil analysis, followed by the recommendation of Trani et al. (2014), which corresponded to the application of $180 \mathrm{~kg} \mathrm{ha}^{-1}$ of $\mathrm{P}_{2} \mathrm{O}_{5}$ simple superphosphate $\left(18 \% \mathrm{P}_{2} \mathrm{O}_{5}\right.$, $16 \%$ calcium and $8 \%$ sulfur) and $80 \mathrm{~kg} \mathrm{ha}^{-1} \mathrm{~K}_{2} \mathrm{O}\left(53 \% \mathrm{~K}^{+}\right.$and $47 \%$ $\left.\mathrm{Cl}^{-}\right)$. The fertilization was made by granular fertilizer. The transformation of the recommended levels into ha, was performed considering the volume of soil in one ha and the volume contained in the pot $\left(\mathrm{dm}^{-3}\right)$.

The experiment was arranged in a randomized block design subdivided in plots, with two factor: A) levels of $\mathrm{N}$ in coverage, and B) irrigation depths, with two replications $(5 \times 2 \times 2)$. The $\mathrm{N}$ fertilization was performed using urea $(45 \% \mathrm{~N})$ diluted in deionized water, in the necessary concentration to get the $\mathrm{N}$ level in the soil according to the following treatments: $25,50,100$, 125 and $150 \mathrm{mg} \mathrm{dm}^{-3}$. At frequency of two days was done the $\mathrm{N}$ fertilization that totalized 12 applications along the arugula growing. To perform the fertigation, a plastic syringe was used $(10 \mathrm{~mL})$, and the volume calibrated with the solution levels in 1.4, 2.8, 5.6, 6.9 and $8.3 \mathrm{~mL}$ for each treatment. The nutrient solution was renewed when the electrical conductivity (EC) of the treatments reached $70 \%$ of the initial $\mathrm{EC}\left(\mathrm{dS} \mathrm{m}{ }^{-1}\right)$.

The $\mathrm{pH}$ and EC were monitored using the portable $\mathrm{pH}$ meter, $\mathrm{pHep}{ }^{\circledR}$ HI98107 and digital conductivity meter. The $\mathrm{pH}$ was kept between 5.5 and 6.5 , and when necessary the nutrient solution was reapplied when the EC of the treatments reached $75 \%$ of the initial $\mathrm{EC}\left(\mathrm{dS} \mathrm{m} \mathrm{m}^{-1}\right)$.

The irrigation depths consisted in a treatment with deficient irrigation management, $50 \%$ of the available water capacity (AWC) and another treatment with full irrigation, $100 \%$ of the AWC (L1 and L2). The applied volume to maintain the preestablished AWC levels was calculated according to the culture evapotranspiration (ETc) determined by the difference between pot mass in consecutive days, by weighing the pot on a semi-analytical balance.

Throughout the experimental trial, soil humidity was monitored by the gravimetric method, keeping the soil of the pots with $50 \%$ and $100 \%$ of the field capacity. Irrigation management was performed using the weighing of the pot with dry and wet soil considering the total volume of the pot.

\section{Evaluated characteristics}

The evaluations were performed in two plants harvested in each pot and the following characteristics were determined: Plant height and number of leaves at 21 and 37 DAT; leaf chlorophyll index (ICF) at 21 DAT; 
leaf area, fresh and dry mass of shoot and leaf $\mathrm{N}$ content were evaluated at 37 DAT.

The plant height was determined with the aid of a millimeter ruler measuring $0.5 \mathrm{~cm}$ above the neck of the plant to the highest leaf. The number of leaves was obtained by manual counting in the plants of each experimental plot. Leaf area was determined by a leaf area integrator LI-COR 3100.

The ICF was measured on fully expanded leaves between 09:00 and 10:00 AM at 21 DAT, using the equipment ClorofiLOG ${ }^{\circledR}$ CFL1030 from manufacturer Falker. The measurement was performed in the center of the leaf width to one third of the leaf length, with three readings, using the average for data analysis. Readings were taken on all leaves of the middle third of the two plants. The assessment was made when the sky was completely clear. The obtained data were transferred to the software ChlorofiLOG $\AA$, separating leaf chlorophyll "a", "b" and total index $\left(\mathrm{ICF}_{\mathrm{a}}, \mathrm{ICF}_{\mathrm{b}}\right.$ and ICF).

The fresh mass of the shoot was taken from the same sample, in which the plant height was determined, weighing the whole plant on a semi-analytical scale. The $\mathrm{N}$ content was determined according to the methodology described by Miyazawa et al. (2009). After washing in deionized water, to obtain the dry mass, the leaves were dried in an oven with forced air circulation at 65 to $70^{\circ} \mathrm{C}$ until constant mass. After drying, the material was ground and weighed $(0.1 \mathrm{~g})$. Sulfur digestion was performed and the $\mathrm{N}$ content determined.

\section{Statistical analysis}

The collected data were submitted to analysis of variance by the $\mathrm{F}$ test adopting the critical level of 5\% probability, and a regression analysis was performed to evaluate the adjustment of the means obtained considering the increased levels of nitrogen and irrigation depths. Statistical analyzes were processed using the statistical program AgroEstat (Barbosa \& Maldonado Júnior, 2015).

\section{RESULTS AND DISCUSSION}

At 21 DAT there was significant interaction between $\mathrm{N}$ levels and irrigation depths only for plant height. $\mathrm{N}$ levels had significant effect on number of leaves, chlorophyll $\mathrm{b}$ and total chlorophyll contents (Table 1). At harvest (37 DAT) there was a significant interaction between the experimental factors ( $\mathrm{N}$ levels $\mathrm{x}$ Irrigation depths) for all studied traits, except for number of leaves or leaf $\mathrm{N}$ content (Table 2).

For the plant height evaluated at 21 DAT, a quadratic effect of the data on L1 was observed, in which the highest estimated average was verified at 150 $\mathrm{mg} \mathrm{dm}{ }^{-3}$ of $\mathrm{N}$, equal to $20.83 \mathrm{~cm}$ plant height, leading to $65 \%$ increase when compared to the lowest levels $(25 \mathrm{mg}$ $\left.\mathrm{dm}^{-3}\right)$ (12.65 $\mathrm{cm}$ plant ${ }^{-1}$ height) (Figure 1A).

The data analysis for L2 presented a linear performance, in which the greatest height was gotten at the level of $150 \mathrm{mg} \mathrm{dm}^{-3}$, with $19.05 \mathrm{~cm}$ height estimated average, with about $30 \%$ increase compared to the lowest level in this study (14.66 cm plant height), (Figure 1A). At harvest, 37 DAT (Figure $2 \mathrm{~A}$ ), there was a quadratic performance of the plant height regarding $\mathrm{N}$ levels, in which the maximum height under L1 was $30.08 \mathrm{~cm}$, achieved at a level of 150 $\mathrm{mg} \mathrm{dm}{ }^{-3}$ of N, an increase of $45 \%$ greater than the level of $25 \mathrm{mg} \mathrm{dm}^{-3}$ (20.75 $\mathrm{cm}$ plant height). Whereas, in L2 the plant height had a linear performance, in which the maximum height was verified at the level of $150 \mathrm{mg} \mathrm{dm}^{-3}$, with height of $30.44 \mathrm{~cm}$, an increase of $57 \%$ compared to the plant height of lowest level (19.41 cm plant height). According to Cavallaro et al. (2009), arugula height is an important parameter, in terms of consumer's choice of this leafy vegetable, usually commercialized in bundles. When associated with the number of leaves emitted per plant, in addition to the expansion of the leaf area, they become important parameters to evaluate the crop productive potential, and therefore, a larger number of leaves attract the consumer's attention, who considers it a product of good quality.

About the number of leaves at 21 and 37 DAT, the highest averages were obtained at $150 \mathrm{mg} \mathrm{dm}^{-3}$, with a linear effect of the $\mathrm{N}$ levels in the two times (Figures 1B and 2B). At 21 DAT, the largest number of leaves was 20 leaves per pot, observed at a level of $150 \mathrm{mg} \mathrm{dm}^{-3}$, with an increase of $31 \%$ in relation to the level of $25 \mathrm{mg} \mathrm{dm}^{-3}$. At 37 DAT applying $150 \mathrm{mg} \mathrm{dm}^{-3}$, the largest number of leaves was 32 leaves per pot, with an increase of $51 \%$ in relation to the level of $25 \mathrm{mg}$ of $\mathrm{N} \mathrm{dm}^{-3}$. Considering the two evaluation dates, it is observed that initially the growth and development were slightly accentuated in relation to plant height and number of leaves. According to Grangeiro et al. (2011), it is a normal performance, as the culture has a slow initial growth until approximately 20 days after sowing (DAS).

In both, 21 and 37 DAT, the best response for plant height was found at the level of $150 \mathrm{mg} \mathrm{dm}^{-3}$, in which the averages in the respective level were 20 and 32 leaves per pot. This result was similar to that observed by BonfimSilva et al. (2015), evaluating the effect of urea levels, the highest number of arugula leaves (23 leaves per pot) was observed at a level of $187 \mathrm{mg} \mathrm{dm}^{-3}$, with an increase of $66.6 \%$ compared to the treatment that did not receive $\mathrm{N}$ fertilization.

For the leaf chlorophyll index (ICF), a significant effect on the $\mathrm{ICF}_{a}, \mathrm{ICF}_{b}$ and ICF was observed only for the $\mathrm{N}$ levels (Table 1) For these characteristics, the estimated averages showed a linear performance. The maximum mean of leaf chlorophyll index found was 45.13, obtained at the level of 150 $\mathrm{mg} \mathrm{dm}{ }^{-3}$, representing a $21 \%$ increase when compared to the level of $25 \mathrm{mg}$ $\mathrm{dm}^{-3}$ (37.4) (Figure 1C). Bonfim-Silva et al. (2015), studying the effect of $\mathrm{N}$ levels ranging from zero to $300 \mathrm{mg} \mathrm{dm}^{-3}$, observed a quadratic effect in which the highest ICF was 56, observed at the level of $205 \mathrm{mg} \mathrm{dm}^{-3}, 45 \%$ more than the observed on the control treatment. In both cases, increasing levels of $\mathrm{N}$ provided greater increases in leaf chlorophyll index in arugula plants. This correlation is attributed to the fact that 50 to $70 \%$ of the total leaf $\mathrm{N}$ are part of chloroplast-associated compounds and the chlorophyll content of the leaves (Chapman \& Barreto, 1997).

The relationship between chlorophyll concentration and $\mathrm{N}$ may be linear until $\mathrm{N}$ is no longer assimilated, and 
Table 1. Average values for main effects and interaction for variables, plant height (HP), number of leaves (NL) and leaf chlorophyll index (ICF) at 21 DAT in arugula culture in response of nitrogen levels and irrigation depths. Jaboticabal, UNESP, 2018.

\begin{tabular}{lccccc}
\hline Irrigation depths & $\mathbf{H P}(\mathbf{c m})$ & $\mathbf{N L}$ (leaves/plant) & $\mathbf{I C F}_{\mathbf{a}}$ & $\mathbf{I C F}_{\mathbf{b}}$ & $\mathbf{I C F}$ \\
\hline $\mathrm{L} 1$ & $15.23 \mathrm{~b}$ & $17.20 \mathrm{a}$ & $31.79 \mathrm{a}$ & $9.08 \mathrm{a}$ & $40.87 \mathrm{a}$ \\
L2 & $16.94 \mathrm{a}$ & $18.10 \mathrm{a}$ & $31.70 \mathrm{a}$ & $10.20 \mathrm{a}$ & $41.97 \mathrm{a}$ \\
\hline
\end{tabular}

Averages followed by the same letter do not differ by the Tukey test ( $>>0.05)$; L1 and L2: 50 and $100 \%$ of the available water capacity, respectively.

Table 2. Average values for main effects and interaction for variables, plant height (HP), leaf number (LN), leaf area (LA), shoot fresh mass (SFM), shoot dry mass (SDM) and nitrogen content $(\mathrm{N})$ at 37 DAT in arugula culture as a response of nitrogen levels and irrigation depths. Jaboticabal, UNESP, 2018.

\begin{tabular}{lcccccc}
\hline $\begin{array}{l}\text { Irrigation } \\
\text { depths }\end{array}$ & HP $(\mathbf{c m})$ & $\begin{array}{c}\text { LN } \\
(\text { leaves/pot) }\end{array}$ & $\begin{array}{c}\text { LA } \\
\left(\mathbf{c m}^{2} / \mathbf{p o t}\right)\end{array}$ & $\begin{array}{c}\text { SFM } \\
(\mathbf{g} / \mathbf{p o t})\end{array}$ & $\begin{array}{c}\text { SDM } \\
(\mathbf{g} / \mathbf{p o t})\end{array}$ & $\begin{array}{c}\mathbf{N} \\
(\mathbf{m g} / \mathbf{k g})\end{array}$ \\
\hline $\mathrm{L} 1$ & $22.90 \mathrm{~b}$ & $26.65 \mathrm{a}$ & $818.60 \mathrm{~b}$ & $53.94 \mathrm{a}$ & $5.79 \mathrm{~b}$ & $25.98 \mathrm{a}$ \\
$\mathrm{L} 2$ & $25.15 \mathrm{a}$ & $27.60 \mathrm{a}$ & $990.98 \mathrm{a}$ & $64.87 \mathrm{a}$ & $7.36 \mathrm{a}$ & $25.72 \mathrm{a}$ \\
\hline
\end{tabular}

Averages followed by the same letter do not differ by the Tukey test ( $>0.05)$; L1 and L2: 50 and $100 \%$ of the available water capacity, respectively. accumulated as nitrate, tending to stabilize the intensity of the green color, reflecting high nitrate content in the plant (Abreu \& Monteiro, 1999; Faquin, 2004). Therefore, it is assumed that the growing of chlorophyll with increasing $\mathrm{N}$ levels in the soil occurs to the extent that it does not accumulate in the form of ammonium and nitrate and is not assimilated by plants. This behavior corroborates with data observed by Viana \& Kiehl (2010), evaluating N levels from zero to $280 \mathrm{mg} \mathrm{dm}^{-3}$ in wheat plants; these authors identified that the highest SPAD index was observed in the level of $240 \mathrm{mg} \mathrm{dm}^{-3}$ of $\mathrm{N}$, showing no greater incremental responses.

Based on the present results, it is known that there is a correlation between the chlorophyll index, leaf

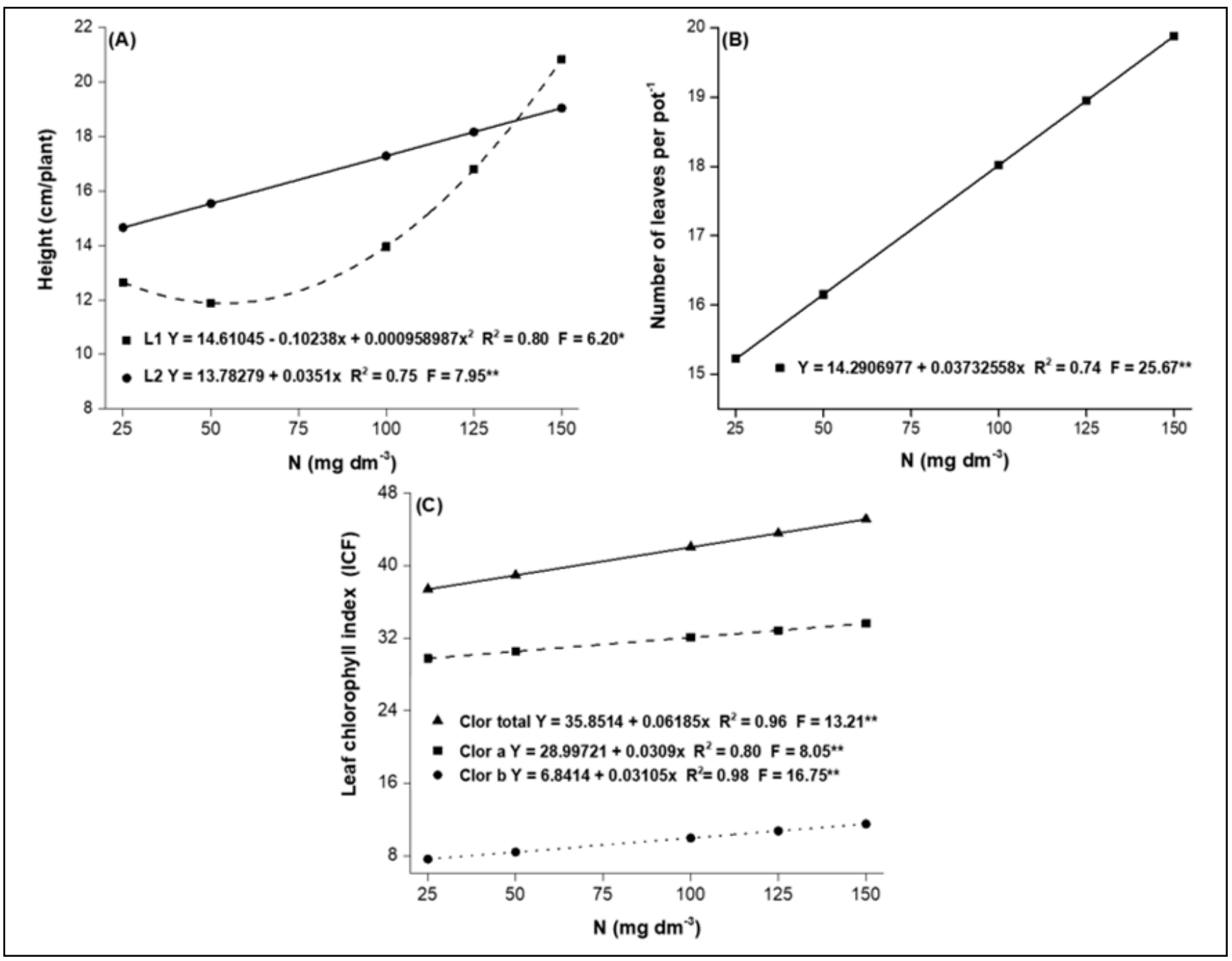

Figure 1. Plant height (A) as a response of interaction and irrigation depths; leaf number (B) and leaf chlorophyll index (ICF) (C) as a response of nitrogen levels in arugula cv. 'Folha larga' at 21 DAT ( $* * *$ corresponding to significant by the $\mathrm{F}$ test at 5 and $1 \%$, respectively); L1 and L2: 50 and 100\% of the available water capacity, respectively. Jaboticabal, UNESP, 2018. 
area and the dry mass of the aerial part. In response to the increase in $\mathrm{N}$ stock, leaf area production increases more than the photosynthetic rate per leaf unit. The production of new leaves creates a new demand for $\mathrm{N}$; the leaves tend to maximize growth because they are producing in photosynthetic tissue. With the increase of the stock and the internal concentration of $\mathrm{N}$ of the plant, the weight of the leaf, leaf area and the rate of liquid assimilation increase, resulting in a higher rate of relative growth; therefore, the internal concentration of $\mathrm{N}$ in the plant becomes an effective predictor of the plant's growth rate and primary productivity (Loustau et al., 2001). In this sense, it can be inferred

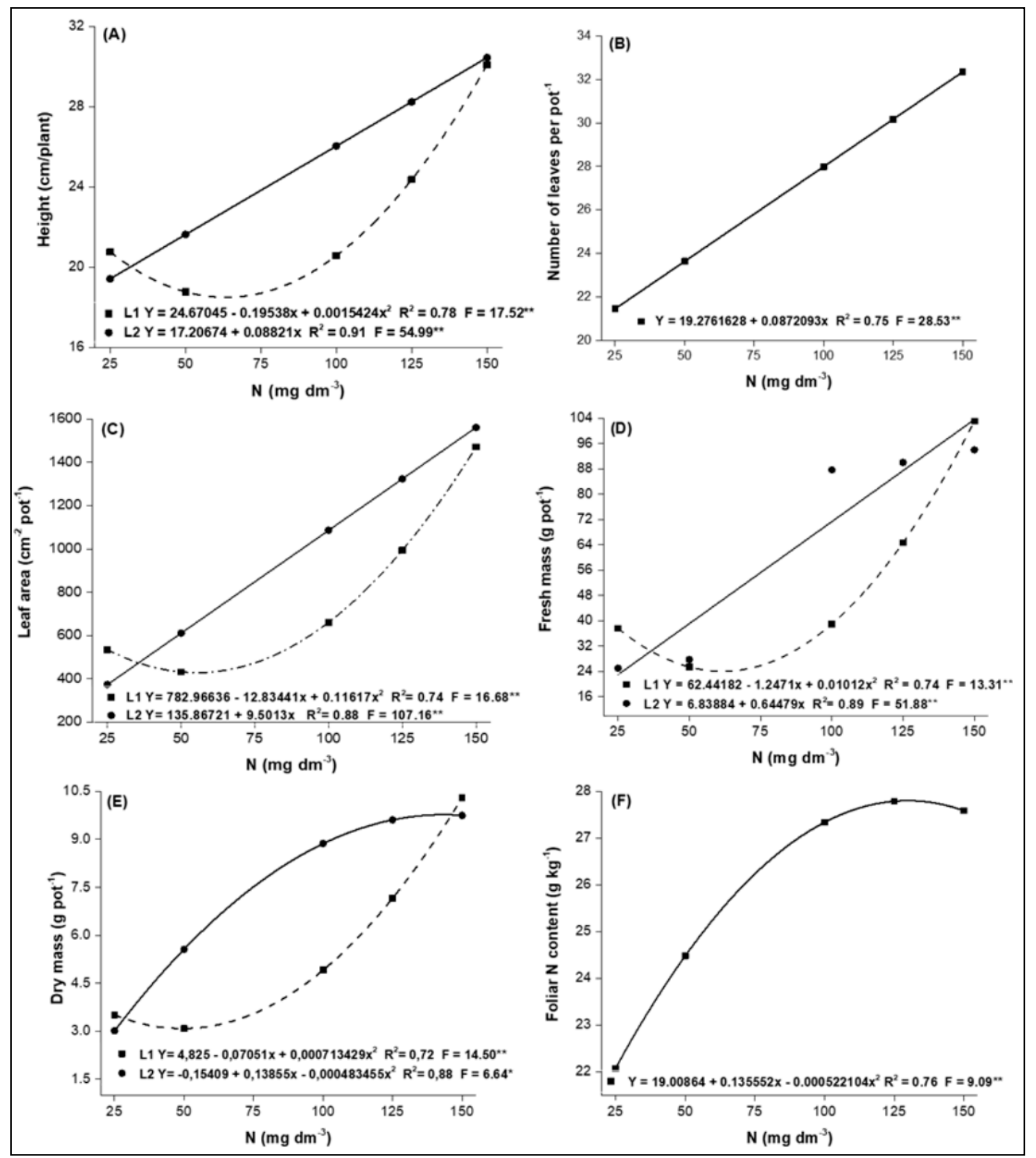

Figure 2. Plant height (A), leaf area (C), fresh mass (D) and dry mass (E) as a response of interaction and irrigation depths; leaf number (B) and nitrogen content $(\mathrm{F})$ as a function of $\mathrm{N}$ levels of arugula cv. 'Folha larga' at $37 \mathrm{DAT}(*$,** corresponding to significant by the $\mathrm{F}$ test at 5 and 1\%, respectively); L1 and L2: 50 and 100\% of the available water capacity, respectively. Jaboticabal, UNESP, 2018. 
that the arugula plants in the highest levels of $\mathrm{N}$ presented the highest chlorophyll index and photosynthesis rates, and consequently, obtained the largest increases in leaf area and in the dry mass of the aerial part.

For $\mathrm{ICF}_{\mathrm{a}}$ and $\mathrm{ICF}_{\mathrm{b}}$, the highest means were observed at $150 \mathrm{mg} \mathrm{dm}^{-3}$ level of $\mathrm{N}, 33.63$ and 11.5 , respectively. Thus, the $\mathrm{ICF}_{\mathrm{a}}$ is $192 \%$ higher than $\mathrm{ICF}_{\mathrm{b}}$. Aguiar Júnior et al. (2010) emphasize the influence of $\mathrm{N}$ on the green intensity of the arugula leaves, improving the visual appearance of the product and directly influencing the consumer's opinion. This parameter also works as an informational basis for identifying this nutrient deficiency. According to Souza et al. (2011) in the arugula, there is a reduction in plants growth, with petioles and leaf vessels presenting a purple color, or tending to a light pink tone, and even an intense yellowing in all leaves, in some cases, old leaves with the purplish and necrotic margins.

For leaf area, a quadratic and linear effect was observed on L1 and L2, respectively for $\mathrm{N}$ levels (Figure 2C). The largest leaf area in L1 was 1471.6 $\mathrm{cm}^{2}$ pot $^{-1}$, obtained at a level of $150 \mathrm{mg}$ $\mathrm{dm}^{-3}$ of $\mathrm{N}$, with $175 \%$ increase compared to $25 \mathrm{mg} \mathrm{dm}^{-3}\left(534.71 \mathrm{~cm}^{2}\right.$ pot $\left.^{-1}\right)$. In L2, the increase in leaf area was still the largest rate evaluated responsible for the highest height $\left(1561.06 \mathrm{~cm}^{2}\right.$ pot $\left.^{-1}\right)$ and, when compared to $25 \mathrm{mg} \mathrm{dm}^{-3}$ showed an increase in leaf area equal or higher than $318 \%$. We also observed that the $\mathrm{N}$ level $25 \mathrm{mg} \mathrm{dm}^{-3}$ in $\mathrm{L} 1$ was the one with the highest estimated average, being 534.71 and $373.4 \mathrm{~cm}^{2}$ pot $^{-1}$ in L2; so, the leaf area production was higher in L1, with $43 \%$ increment, but the largest leaf area was observed in the level of $150 \mathrm{mg}$ $\mathrm{dm}^{-3}$ of $\mathrm{N}$ in both levels.

At harvest, there was a significant effect of the treatments on the traits of fresh and dry mass evaluated at 37 DAT. For the estimated fresh mass averages in L1 (Figure 2D), there was a quadratic effect, obtaining $103.1 \mathrm{~g} \mathrm{pot}^{-1}, 150$ $\mathrm{mg} \mathrm{dm}{ }^{-3}$, with a $174 \%$ increase when compared to $25 \mathrm{mg} \mathrm{dm}^{-3}$ (37.59 $\left.\mathrm{g} \mathrm{pot}^{-1}\right)$.

The fresh mass in L2 responded linearly, being observed a maximum average of $93.96 \mathrm{~g} \mathrm{pot}^{-1}$, verified in the level of $150 \mathrm{mg} \mathrm{dm}^{-3}$ of $\mathrm{N}$, corresponding to an increase of $276 \%$ in relation to the lowest evaluated level $\left(25 \mathrm{mg} \mathrm{dm}^{-3}\right)$.

For dry mass there was a similar performance in $\mathrm{L} 1$, in which maximum mean estimated by the equation was $10.3 \mathrm{~g} \mathrm{pot}^{-1}$. This was observed at the level of $150 \mathrm{mg} \mathrm{dm}^{-3}$ of $\mathrm{N}$, representing a $193 \%$ increase when compared to a level of $25 \mathrm{mg} \mathrm{dm}^{-3}$ of $\mathrm{N}$ (3.51 $\left.\mathrm{g} \mathrm{pot}^{-1}\right)$ (Figure 2E). For L2, the highest average verified for dry mass was $9.8 \mathrm{~g} \mathrm{pot}^{-1}$, being observed in the level of $143.3 \mathrm{mg}$ $\mathrm{dm}^{-3}$ of $\mathrm{N}$, representing a $225 \%$ increase over the level of $25 \mathrm{mg} \mathrm{dm}^{-3}(3.01 \mathrm{~g}$ pot $\left.^{-1}\right)$. Knowing that the culture has a slow initial growth, consequently larger increments in the fresh and dry mass are observed later in the cycle, which was also verified by Grangeiro et al. (2011). For dry mass, according to the authors, the highest accumulation was observed in the period from 25 to 30 DAS. During this period an accumulation was observed of approximately $56 \%$ of the total accumulated by the plant.

The $\mathrm{N}$ content in the plant was not significant for the irrigation depths, thus, for the estimated averages there was a quadratic effect; the highest $\mathrm{N}$ content was found at the level of 129 $\mathrm{mg} \mathrm{dm}{ }^{-3}\left(27.8 \mathrm{~g} \mathrm{~kg}^{-1}\right)$, corresponding to a $26 \%$ increase over the $25 \mathrm{mg} \mathrm{dm}^{-3}$ level $\left(22.07 \mathrm{~g} \mathrm{~kg}^{-1}\right)$. $\mathrm{N}$ in particular participates in the structure of pigments such as chlorophyll, amino acids, proteins, as a constituent of enzymes and some processes such as photosynthesis and respiration (Taiz et al., 2017); therefore, the levels provided increases in $\mathrm{N}$ content and consequently in productivity, thus making $\mathrm{N}$ essential for crop growth and development.

However, supplying $150 \mathrm{mg} \mathrm{dm}^{-3} \mathrm{~N}$ along with full irrigation management provided substantial increase in height, leaf area and fresh mass of shoots.

Nevertheless, irrigation management did not significantly influence $\mathrm{ICF}_{\mathrm{a}}, \mathrm{ICF}_{\mathrm{b}}$ and ICF, and the level of $150 \mathrm{mg} \mathrm{dm}^{-3}$ of $\mathrm{N}$ was responsible for the respective levels of leaf chlorophyll index of 33.66, 11.5 and 45.1.

Shoot dry mass was affected by nitrogen levels and by the management of deficient and full irrigation: $150 \mathrm{mg}$ $\mathrm{dm}^{-3}\left(10.3 \mathrm{~g} \mathrm{pot}^{-1}\right)$ and $143 \mathrm{mg} \mathrm{dm}^{-3}(9.8$ $\left.\mathrm{g} \mathrm{pot}^{-1}\right)$, respectively.
Nitrogen content was not affected by irrigation management, hence, the 129 $\mathrm{mg} \mathrm{dm}{ }^{-3} \mathrm{~N}$ level provided the highest content of $27.8 \mathrm{~g} \mathrm{~kg}^{-1}$.

\section{ACKNOWLEDGMENTS}

This study was financed in part by the Coordenação de Aperfeiçoamento de Pessoal de Nível Superior, Brasil (CAPES), Finance Code 001, by scholarship to the first author.

\section{REFERENCES}

ABREU, JBR; MONTEIRO, FA. 1999. Produção e nutrição do capim Marandu em função de adubação nitrogenada e estádios de crescimento. Boletim de Indústria Animal 56: $137-146$

AGUIAR JÚNIOR, RA; GUISCEM, J; SILVA, A; FIGUEIREDO, R; CHAVES, A; PAIVA, J; SANTOS, F. 2010. Interferência de doses de nitrogênio na produção de área foliar, biomassa fresca e seca de rúcula. Horticultura Brasileira 28: 3970-3974.

ALEMAN, C; SAAB, N; MOREIRA, A; MARQUES, P. 2014. Cultivo de alface irrigada sob diferentes coberturas de solo. II INOVAGRI International Meeting. p.27322736.

ANDRE, RGB; GARCIA, A. 2015. Alguns aspectos climáticos do município de Jaboticabal-SP. Nucleus 12: 263-269.

ARAGÃO, VF; FERNANDES, PD; GOMES FILHO, RR; CARVALHO, CM; FEITOSA, HO; FEITOSA, EO. 2012. Produção e eficiência no uso de água do pimentão submetido a diferentes lâminas de irrigação e níveis de nitrogênio. Revista Brasileira de Agricultura Irrigada 6: 207-216.

BARBOSA, JC; MALDONADO JÚNIOR, W. 2015. Experimentação agronômica \& AgroEstat: sistemas para análises estatísticas de ensaios agronômicos. Multipress. p.76.

BILIBIO, C; CARVALHO, JA; MARTINS, M; REZENDE, FC; FREITAS, EA; GOMES, LA. 2010. Desenvolvimento vegetativo e produtivo da berinjela submetida a diferentes tensões de água no solo. Revista Brasileira de Engenharia Agricola e Ambiental 14: 730-735.

BONFIM-SILVA, EM; CLÁUDIO, AA; LEMES, CS; BÄR, CSLL; PACHECO, AB. 2015. Nitrogênio na produção, índice de clorofila e uso de água no cultivo de rúcula. Enciclopédia Biosfera 11: 1386-1396.

CASTELLANE, PD. 1994. Nutrição mineral e qualidade de olerícolas folhosas. SÁ, ME; BUZZETI S, (coords). Importância da adubação na qualidade dos produtos agrícolas. São Paulo: Ícone.

CAVALLARO, J; TRANI, PE; PASSOS, FA; KUHN, N; TIVELLI, SW. 2009. Rocket salad and tomato yield correlated to organic 
and mineral fertilization N and P. Bragantia 68: $347-356$

CHAPMAN, SC; BARRETO, HJ. 1997. Using a chlorophyll meter to estimate specific leaf nitrogen of tropical maize during vegetative growth. Agronomy Journal 89: 557-562.

CLAESSEN, MEC. 1997. Manual de métodos de análise de solo. Embrapa Solos. Available: https://www.agencia.cnptia.embrapa.br/ Repositorio/Manual+de+Metodos_000fzvho tqk02wx5ok0q43a0ram31wtr.pdf. Accessed: April 9, 2018.

COELHO, AP; FARIA, RT; DALRI, AB; PALARETTI, LF; ZANINI, JR. 2018. Clorofilômetro portátil como forma de manejo da irrigação e adubação nitrogenada em aveiabranca. Revista Brasileira de Agricultura Irrigada 12: 2542.

FAQUIN, V. 2004. Nutrição mineral e diagnose do estado nutricional das hortaliças. UFLA: FAEPE. p.88.

FILGUEIRA, FAR. 2000. Novo manual de olericultura: Agrotecnologia moderna na produção e comercialização de hortaliças. Viçosa: UFV. p.402.

GRANGEIRO, LC; FREITAS, FCL; NEGREIROS, MZ; MARROCOS, STP; LUCENA, RRM; OLIVEIRA, RA. 2011. Crescimento e acúmulo de nutrientes em coentro e rúcula. Revista Brasileira de
Ciências Agrárias 6: 11-16.

KASSAM, A; DOORENBOS, J. 1994. Efeito da água no rendimento das culturas. FAO. Estudos FAO. Irrigação e Drenagem.

LOUSTAU, D; HUNGATE, B; DRAKE, BG; ROY, J; SAUGIER, B; MOONEY, HA. 2001. Water, nitrogen, rising atmospheric $\mathrm{CO}_{2}$, and terrestrial productivity. In: ROY, J.; SAUGIER, B.; MOONEY, HA (eds). Terrestrial Global Productivity. p.123-167.

MAIA, AFCA; MEDEIROS, DC; LIBERALINO FILHO, J. 2007. Adubação orgânica em diferentes substratos na produção de mudas rúcula. Revista Verde de Agroecologia e Desenvolvimento Sustentável 2: 89-95.

MIYAZAWA, M; PAVAN, MA.; MURAOKA, T; CARMO, CAFS; MELO, WJ. 2009. Análises químicas de tecido vegetal, in: Manual de análises químicas de solos, plantas e fertilizantes, $2^{\text {nd }}$ ed.., ed. SILVA, FC. (org). Brasília: Embrapa. 191-223.

PIŚLEWSKA-BEDNAREK, M; NAKANO, RT; HIRUMA, K; PASTORCZYK, M; SANCHEZVALLET, A; SINGKARAVANIT-OGAWA, S; CIESIOŁKA, D; TAKANO, Y; MOLINA, A; SCHULZE-LEFERT, P; BEDNAREK, P. 2018. Glutathione transferase U13 functions in pathogen-triggered glucosinolate metabolism. Plant Physiology 176: 538-551.

PURQUERIO, LFV; DEMANT, LAR; GOTO, R;
BOAS, V; LYRA, R. 2007. Efeito da adubação nitrogenada de cobertura e do espaçamento sobre a produção de rúcula. Horticultura Brasileira 25: 464-470.

SANTOS, HG; JACOMINE, PKT; ANJOS, LHC; OLIVEIRA, VA; LUMBRERAS, JF; COELHO, MR; ALMEIDA, JA; ARAUJO FILHO, JC; OLIVEIRA, JB; CUNHA, TJF. 2018. Sistema brasileiro de classificação de solos. Embrapa Solos. Available: https:// www.embrapa.br/solos/sibcs. Accessed: April 9, 2018.

SOUZA, LFG; RODRIGUES, MA; SILVA, MLP; SILVA, GS; CECÍLIO FILHO, AB. 2011. Caracterização de sintomas de excesso de micronutrientes e deficiência de macronutrientes em rúcula. Horticultura Brasileira 29: 3932-3939.

TAIZ, L; ZEIGER, E; MOLLER, IM; MURPHY, A. 2017. Fisiologia e desenvolvimento vegetal. 6. ed. Porto Alegre: Artmed. p. 888.

TRANI, PE; PURQUÉRIO, LFV; FIGUEIREDO, GJB; TIVELLI, SW; BLAT, SF. 2014. Calagem e adubação da alface, almeirão, agrião d'água, chicória, coentro, espinafre e rúcula. Campinas: IAC. p.16.

VIANA, EM; KIEHL, JDC. 2010. Doses de nitrogênio e potássio no crescimento do trigo. Bragantia 69: 975-982. 